\title{
Comparison of forest regeneration in two sites with different primate abundances in Northwestern Ecuador
}

\author{
Bayron R. Calle-Rendón ${ }^{1}$, Mika Peck², Sara E. Bennett ${ }^{3}$, Citlalli Morelos-Juarez ${ }^{4} \&$ \\ Felipe Alfonso ${ }^{5}$ \\ 1. Máster Oficial en Biodiversidad en Áreas Tropicales y su Conservación, Universidad Internacional Menéndez Pelayo \\ (UIMP), c/Isaac Peral 23, Madrid, España; brcalle@unal.edu.co \\ 2. University of Sussex, JMS Building, Falmer, Brighton BN1 9QJ, UK; m.r.peck@sussex.ac.uk \\ 3. Fundación Maikuchiga, Carrera 6 No. 4-81 Leticia, Colombia; saramicos@gmail.com \\ 4. University of Sussex, JMS Building, Falmer, Brighton BN1 9QJ, UK; c.morelos-juarez@sussex.ac.uk \\ 5. Proyecto Washu, Avenida Eloy Alfaro y Angel Saenz, Quito, Ecuador; felipe.alfonso.cortes@gmail.com
}

Received 10-III-2015. C Corrected 09-XI-2015. Accepted 07-XII-2015.

\begin{abstract}
There is increasing evidence that large-bodied primates play important roles as seed dispersers and in the maintenance of tree diversity in forest ecosystems. In this study we compared forest regeneration at two sites with differing primate abundances in the Ecuadorian Chocoan rainforest. We predicted: (1) significant differences in primate abundance between the two sites; (2) higher understory tree species richness and density at the site with greater primate abundance; (3) the site with lower primate abundance characterized by tree species dispersed by non-primate biotic agents and/or abiotic factors. We compared two sites, Tesoro Escondido (TE) a campesino cooperative, and the El Pambilar (EP) wildlife refuge that both maintain populations of mantled howler monkey (Alouatta palliata), the brown-headed spider monkey (Ateles fusciceps fusciceps) and the capuchin monkey (Cebus capucinus). We characterized canopy structure by point-quadrant sampling, determined primate abundance and sampled seedlings/saplings in $1 \mathrm{~m}^{2}$ plots, classifying tree species based on three dispersal syndromes: adapted for primate dispersal, dispersed by other biological agents, and abiotic dispersal. We compared sites in terms of primate abundance (groups and individuals observed per day) and regeneration characteristics (overall density, species richness, and dispersal syndrome). We carried out within site comparisons and constructed understory tree species accumulation curves. Overall the forests were structurally similar - with significantly higher densities of $A$. f. fusciceps at TE. Encounter rates for the other two primate species were similar at both sites. Understory tree density and species richness was significantly higher in TE with no stabilization of tree species accumulation curves. The species accumulation curve for understory trees at EP stabilized. Higher densities and species richness of primate dispersed tree species were observed at TE, with non-primate biotically dispersed tree species the dominant dispersal syndrome at both sites. Our observations are consistent with those from other studies investigating the role of large-bodied frugivorous primates in forest regeneration, and point to a general pattern: future lowland tropical forest tree diversity depends on maintaining robust populations of large primate species in these systems. It is highly probable that the maintenance of high levels of tree diversity in Chocoan rainforests is dependent on the conservation of its largest resident primate, the critically endangered brown-headed spider monkey (A.f. fusciceps). Rev. Biol. Trop. 64 (2): 493-506. Epub 2016 June 01.
\end{abstract}

Key words: Alouatta palliata, Ateles fusciceps fusciceps, Cebus capucinus, biogeographic Chocó region, seed dispersal, hotspots, forest regeneration.

Hotspots are ecosystems that have been designated important for biodiversity conservation due not only to their high species diversity, high levels of endemism, and relatively small area, but also to a high rate of current destruction (Myers, 1988, 1990; Myers, Mittermeier, Mittermeier, da Fonseca, \& Kent, 2000). Many tropical rainforests, possibly supporting over half of the world's species, are classified as hotspots (Myers, 1988, 1990; Mittermeier, 
Myers, Thomsen, da Fonseca, \& Olivieri, 1998; Olson \& Dinerstein, 1998, 2002; Myers et al., 2000). In recent decades alteration and loss of these ecosystems has been increasing due to logging, large fires, large scale deforestation, loss of fauna, and global climate change (Corlett \& Primack, 2008), all of which justify immediate action to promote and ensure their conservation.

Various theories have attempted to account for the extremely high species richness of lowland tropical rainforests, among which are those highlighting the importance of animal seed dispersal as a mechanism for generating and maintaining plant diversity (Barrera, Zambrano, \& Stevenson, 2008; Carson, Anderson, Leigh, \& Schnitzer, 2008; Dalling \& John, 2008; Muller-Landau, 2008; Nuñez-Iturri \& Howe, 2007; Nuñez-Iturri, Olsson, \& Howe, 2008; Schnitzer, Mascaro, \& Carson, 2008; Stevenson, 2011; Terborgh et al., 2008; Zimmerman, Thompson, \& Brokaw, 2008). For example, Janzen (1970) and Connell (1971) proposed a model of negative density dependence, in which plant recruitment rates are lower for seeds that fall under or near the parent tree than for those that are dispersed a distance away.

Primates represent $25-40 \%$ of frugivorous animal biomass in tropical forests (Chapman, 1995) and are increasingly threatened (Mittermeier et al., 2012). Many species of both the Old (McConkey, Aldy, Ario, \& Chivers, 2002; Wrangham, Chapman, \& Chapman, 1994) and New World primates (Andresen, 2002; Knogge, Heymann, \& Tirado, 1998; Link \& Di Fiore, 2006; Stevenson, 2000; Wehncke, Hubbell, Foster, \& Dalling, 2003) are seed dispersers. In the neotropics, atelids, especially Ateles and Lagothrix, are characterized by their wide ranging behavior, by their dietary preference for large quantities of the fruit from a wide range of tree species, and their tendency to swallow and defecate intact large seeds far from where they were found (Defler \& Defler, 1996; Link $\&$ Di Fiore, 2006; Stevenson, 2000).

Because of this it had been suggested that decreasing primate populations could result in important ecosystem changes due to diminished recruitment of their large seeded food plant species and proportionally greater representation of smaller seeded species dispersed by abiotic or other biotic agents (Effiom, Nuñez-Iturri, Smith, Ottosson, \& Olsson, 2013; Nuñez-Iturri \& Howe, 2007; Nuñez-Iturri et al., 2008; Terborgh et al., 2008). Recent studies have confirmed the influence of primates and other mammals on forest seedling dynamics. Terborgh et al. (2008), for example, found that seedling density and the proportion of seedlings dispersed biotically was higher at sites with greater mammal density. In the forests of the Peruvian Amazon Nuñez-Iturri and Howe (2007), and Nuñez-Iturri et al. (2008) found that species richness, seedling density and the proportion of seeds dispersed biotically was significantly higher in areas with greater abundance of large (atelid) and medium (cebid) primates. In the forests of Southeastern Nigeria, habitat of the critically endangered Cross River gorilla (Gorilla gorilla diehli), the abundance of primates also influenced seedling density (Effiom et al., 2013).

This is the first investigation to analyze the effect of density and abundance of primates on the richness, density, and recruitment patterns of seedlings in the lowland rainforests of Northwestern Ecuador, part of the Chocó biogeographic region (which has been classified a global conservation hotspot) (Myers et al., 2000). Three primate species are found there: the brown-headed spider monkey (Ateles fusciceps fusciceps), endemic to Ecuador and critically endangered (CR) and one of the 25 most endangered primates in the world (Mittermeier et al., 2012); the mantled howler (Alouatta palliata), and the capuchin monkey (Cebus capucinus), both classified as vulnerable species (VU) (Tirira, 2001, 2008). Social, political, economic, and cultural processes including high levels of poverty amongst rural peasants and indigenous people, unsustainable hunting, commercial logging, the establishment of huge oil palm plantations, and the lack of governmental policies recognizing the ecological value of zones outside protected 
areas- are accelerating forest loss and decimating animal populations in the region (Justicia, 2007; Sierra \& Stallings, 1998; Southgate \& Whitaker, 1992).

The aim of this study was to compare forest regeneration at two sites differing in primate abundance. Our hypothesis is that regeneration in the lowland rainforests of Northwestern Ecuador, is dependent on the ecological services provided by primates. Our predictions were: (1) primate abundance will differ between the two sites; (2) density and richness of seedlings and saplings will be greater at the site with higher primate abundance; (3) the site with lower primate abundance will be characterized by higher seedling and saplings density and richness of tree species dispersed abiotically, or by other biotic dispersers (e.g. birds, bats).

\section{MATERIALS AND METHODS}

Study area: The study was undertaken in Esmeraldas Province, Northwestern Ecuador, in lowland rainforest, within the Cayapas river basin characterized by elevations between 200 and $800 \mathrm{~m}$ and slopes from 10 to $100 \%$. Annual precipitation varies from 3000 to 5000 $\mathrm{mm}$, distributed unimodally (Ministerio del Ambiente, 2011); July and August are typically the driest months (Moscoso \& Peck, 2012).

We selected two sites $8.8 \mathrm{~km}$ apart, on opposite sides of the Chontaduro river: Tesoro Escondido (TE: 00³2'30.8" N - 7908'41.7" W) and the El Pambilar Wildlife Refuge (EP: $\left.00^{\circ} 36^{\prime} 58.1 " \mathrm{~N}-79^{\circ} 10^{\prime} 10.4 " \mathrm{~W}\right)$. TE is a 3000 ha campesino cooperative which has been inhabited for at least 40 years and which subsists mainly on the cultivation of cacao. There has been occasional small scale logging due to the expansion of crops (Moscoso \& Peck, 2012). Recently scientific fieldworkers have been working with the local community to conserve the brown-headed spider monkey population found at the site, integrating scientific research and sustainable livelihoods projects. In the last five years EP was declared a state protected area of 3123 ha. It had previously been licensed to a timber company that had not begun exploitation. Indigenous Chachi populations reside close by; their main activities including fishing, hunting, gathering wild forest fruits, cultivating cacao and other crops, and logging (Ministerio del Ambiente, 2011). EP was accessible to Chachi indigenous hunters, who traditionally hunt spider monkeys for their meat, in contrast to peasant farmers at TE, who do not kill primates. This may be the cause of lower primate abundance expected in EP.

Forest structure: We assumed that both sites were comparable both climatically and edaphically due to their proximity and similar elevations measured at 30 random points ( $424 \pm$ $83 \mathrm{~m}$ in TE and $359 \pm 37 \mathrm{~m}$ in EP). To ascertain whether the forest at the two sites were structurally similar we sampled canopy trees as this would reflect past ecological conditions rather than the current status, that is better reflected by seedlings (Stevenson, 2011). In July, 2013, we selected 20 sampling points every 200 $\mathrm{m}$ along the primate census transect (see the Primate Census section). Using point-quadrant methodology to characterize the vegetation (Ganzhorn, Rakotondranary, \& Ratovonamana, 2011), we delimited four quadrants based on the cardinal compass points: NW, NE, SE, and $\mathrm{SW}$. At each quadrant we measured the distance from the sample point to the nearest tree $\geq 10 \mathrm{~cm} \mathrm{DBH}$ (diameter breast high). Trees of this size have been used previously to characterize canopy vegetation in tropical rainforests (Calle-Rendón, Moreno, \& Cárdenas-López, 2011; Casas, 2010). We calculated tree density per hectare as, $\mathrm{N}=10000 / \mathrm{d}^{2}$ where $\mathrm{d}$ is the average of the measured distances to the trees in each quadrant; $d^{2}$ provides an estimate of the average area in which one of the measured trees occurs (Ganzhorn et al., 2011), $\mathrm{d}^{2}$ provides a basal area per hectare estimate of $\mathrm{G}=(10000 \mathrm{~B}) /\left(4 \mathrm{~d}^{2}\right)$, where $\mathrm{B}$ is the sum of the basal areas of the four sampled trees. The same experienced observer estimated the tree heights for all samples to provide an estimate of average height at each site. In addition, we quantified percentage canopy closure by drawing a $1 \times 1 \mathrm{~cm}^{2}$ grid on a transparent plastic sheet 
fastened to the bottom of a plastic bottle whose base had been removed. At each sampling point we looked up at the canopy through the vertically positioned bottle and counted the number of squares occupied by vegetation or sky. We estimated percent closure as the number of squares with vegetation cover divided by total number of squares multiplied by 100 (modified from Jennings, Brown, \& Sheil, 1999).

Primate census: To determine whether there was a significant difference in primate abundance between sites, we used data from transect surveys carried out between February and May 2013 at both sites. We analyzed $4 \mathrm{~km}$ linear transects marked every $25 \mathrm{~m}$ by adapting the standardized technique proposed by Peres (1999). The observer carried out the survey (not always on consecutive days) starting at 8:00 and walking at a constant velocity of $1 \mathrm{~km} / \mathrm{h}$. When the transect was completed, the observer waited for one hour and returned back on the same trail, for a total daily transect distance of $8 \mathrm{~km}$. When a group of animals or a solitary individual was detected, the number was recorded and the perpendicular distance to the center of the group measured. Auditory detections and censuses from days of heavy rain were not included. The total TE transect distance was $208 \mathrm{~km}$; EP total transect distance was $88 \mathrm{~km}$, representing a total of 26 and 11 days, respectively surveyed during the four month period.

Forest regeneration and dispersal syndromes: To determine whether there were any differences in sapling recruitment, we established 30 random $1 \times 1 \mathrm{~m}$ plots beside each transect at both sites (excluding forest clearings due to possible confounding effects of increased sapling growth that might result from increased light availability) at the end of March and beginning of April, 2013. The plots were located up to $60 \mathrm{~m}$ away on both sides of the transect, with a total sampling area of $480000 \mathrm{~m}^{2}$ at each site (Nuñez-Iturri et al., 2008). Within each plot we counted and collected all non-herbaceous and non-liana plants within two size classes: seedlings (DBH $<1 \mathrm{~cm}$ and height $<1.5 \mathrm{~m})$ and saplings $(1 \leq$ $\mathrm{DBH} \leq 5 \mathrm{~cm}$ and height $\geq 1.5 \mathrm{~m}$ ) (modified from Melo, \& Vargas, 2002), and identified each to species in the National Herbarium of Ecuador (QCNE). Using information from the literature and local knowledge, each species was categorized according to dispersal mode: (1) plants with primate dispersed seeds (operationally defined as fruits with seeds $\geq 15 \mathrm{~mm}$ in length excluding species known to be dispersed mainly by birds or bats); (2) plants with fruits whose seeds are $<15 \mathrm{~mm}$ in length dispersed by primates as well as other biotic agents (birds, bats, etc.); and (3) plants abiotically dispersed, whose seeds are disseminated by wind, water or autochorically dispersed (Nuñez-Iturri et al., 2008).

We compared characteristics of canopy structure at the two sites using the Mann-Whitney $U$ test for density, basal area, and canopy closure (due to the lack of normal distribution) and the $t$ test for heights, which were distributed normally according to a Shapiro-Wilk test. We calculated total primate abundance and the abundance of each species (groups and individuals/day) and compared sites using a MannWhitney U test. We also used a Kruskal-Wallis test to compare the abundance of the three species within the same site, and the NewmanKeuls multiple comparison to compare the abundances of pairs of primate species. Forest regeneration was compared between sites using Mann-Whitney U test for species richness and the number of plants per plot. In addition, using species abundance data from each plot and the Chao1 non-parametric estimator (Chao, 1984), we estimated the number of sapling species at each site using ESTIMATES 9.1.0 software (Colwell, 2013). This is estimated as, Chao1 $=\mathrm{Sp}_{\mathrm{obs}}+\left(\mathrm{a}^{2} / 2 \mathrm{~b}\right)$, where $\mathrm{Sp}_{\mathrm{obs}}$ is the observed species richness, $a$ is the number of singletons (species with one individual) and $b$ the number of doubletons (species with two individuals), using 100 randomizations. Species accumulation curves were generated to further investigate pattern in species richness. Finally, for each dispersal syndrome we analyzed whether 
total species richness and seedling density differed between sites using a Newman-Keuls multiple comparison test compare differences among pairs of dispersal syndrome. All statistical analyses were carried out using STATISTICA 8.0 software (StatSoft, Inc., Tulsa, USA).

\section{RESULTS}

Forest structure: There was no significant difference in basal area, canopy closure, and height $(\mathrm{Z}=1.92, \mathrm{P}=0.054 ; \mathrm{Z}=0.89, \mathrm{P}$ $=0.37$ and $\mathrm{t}=0.48, \mathrm{P}=0.63$ respectively) between forest at either site. However tree density at TE (TE $=971.4 \pm 553.8$ ind. / ha; EP $=629.1 \pm 303.3$ ind. $/ \mathrm{ha}$ ) was seen to be significantly higher $(\mathrm{Z}=2.40, \mathrm{P}=0.01)($ Table 1$)$.

Primate abundance: TE showed significantly higher primate abundance than EP in terms of groups seen per day $(3.07 \pm 1.29$ groups/day in TE and $0.7 \pm 1.19$ groups/day in $\mathrm{EP}, \mathrm{Z}=3.82, \mathrm{P}=0.0001$ ) and individuals per day $(9.4 \pm 5.1$ ind. / day in TE and $3.2 \pm$ 6.9 ind. / day in EP, $Z=3.15, P=0.0015$ for individuals). In TE, spider monkeys and howler monkeys were the most abundant species $(2.15$ \pm 1.08 and $0.76 \pm 0.76$ groups per day, respectively) and detected more often than at EP (0.36 \pm 0.5 howler groups per day, spider monkeys at an average of $0.09 \pm 0.3$ groups per day) (Fig. 1A). In contrast, capuchins were more common at $\mathrm{EP}(0.27 \pm 0.64$ groups / day $)$ than at TE $(0.15 \pm 0.54$ groups per day $)$. The daily encounter rates for individuals at TE parallels the pattern for groups detected, with average values of $6.4 \pm 6.8 \mathrm{ind}$./day for spider monkeys, $2.6 \pm 3.2$ ind. / day for howlers, and $0.26 \pm$ $1.04 \mathrm{ind} . /$ day for capuchins. The opposite pattern was seen in EP, where the daily average
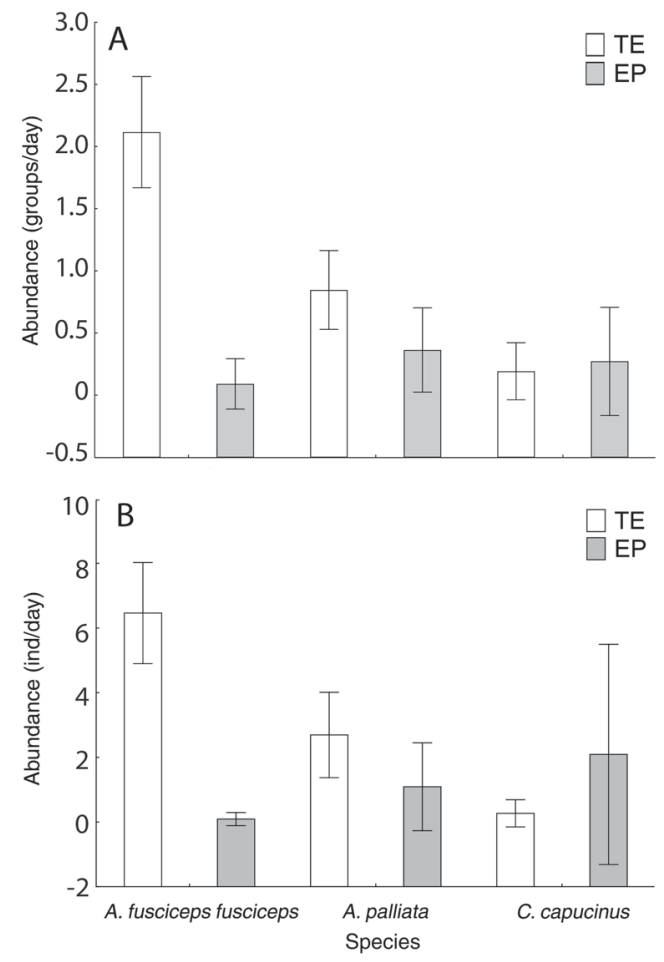

Fig. 1. Primate abundance of three species at two sites in Northwestern Ecuador. (A) groups; (B) individuals. Average and the $95 \%$ confidence intervals. TE: Tesoro Escondido; EP: El Pambilar.

TABLE 1

Structure of the forest canopy at two sites in Northwestern Ecuador

\begin{tabular}{lcccccc} 
Variable & Study Area & Average & Minimum & Maximum & s.d & CV \\
$\mathrm{G}\left(\mathrm{m}^{2} / \mathrm{ha}\right)$ & TE & 217.9 & 51.5 & 667.4 & 171.2 & 78.5 \\
& EP & 174.0 & 29.5 & 910.7 & 214.5 & 123.2 \\
$\mathrm{~N}$ (ind./ha) & TE & 971.4 & 381.8 & 2544.3 & 553.8 & 57.0 \\
& EP & 629.1 & 282.2 & 1366.6 & 303.3 & 48.2 \\
$\mathrm{H}(\mathrm{m})$ & TE & 25.7 & 16 & 38 & 7.17 & 27.9 \\
& EP & 24.6 & 13 & 38 & 7.24 & 27.4 \\
$\Theta(\%)$ & TE & 91.3 & 15.7 & 100.0 & 20.5 & 22.5 \\
& EP & 87.3 & 13.9 & 100.0 & 28.2 & 32.3 \\
\hline
\end{tabular}

G: basal area per hectare; N: tree density per hectare; H: height; $\Theta$ : canopy closure; TE: Tesoro Escondido; EP: El Pambilar. 
of capuchins encountered was highest (2.09 \pm 5.06 ind./day), followed by howlers (1.09 $\pm 2.02 \mathrm{ind}$./day), then spider monkeys $(0.09 \pm$ 0.3 ind./day) (Fig. 1B). Comparison of species abundance estimates between sites revealed a significant difference only for the spider monkey $(\mathrm{Z}=4.45, \mathrm{P}<0.0001$ for groups and $\mathrm{Z}=$ $4.53, \mathrm{P}=0.0001$ for individuals). There were no significant difference in abundance between sites for howlers $(\mathrm{Z}=1.34, \mathrm{P}=0.17$ for groups, and $Z=1.34, P=0.17$ for individuals), or for capuchins $(\mathrm{Z}=-0.46, \mathrm{P}=0.64$ for groups, and $\mathrm{Z}=-0.56, \mathrm{P}=0.57$ for individuals). Within TE there were significant differences in abundance of species measured both as groups $(\mathrm{H}=39.66$, $\mathrm{P}<0.0001)$ and of individuals $(\mathrm{H}=41.2, \mathrm{P}<$ $0.0001)$. At EP there was no significant difference in abundance between species $(\mathrm{H}=2.24$, $\mathrm{P}=0.32$ for groups and $\mathrm{H}=2.24, \mathrm{P}=0.32$ for individuals). Subsequent analysis of abundance at the TE site, using the Newman-Keuls test, confirmed that there were significant differences between all species.

Forest regeneration and dispersal syndromes: We collected 68 plant species in TE and 32 in EP. The most abundant species at TE were Chrysochlamys membranacea (Clusiaceae), Pourouma minor (Cecropiaceae) and Pseudolmedia rigida (Moraceae). Tetragastris varians (Burseraceae) and Ossaea sp.
(Melastomataceae) were most abundant in EP. There were 22 species exclusive to TE and 9 to EP. The average number of species per square meter was $3 \pm 1.46$ in $\mathrm{TE}$ and $1.6 \pm 1.47$ in EP. There were a total of 113 plants in the TE sample and 56 in EP. Total plant density per square meter was $3.8 \pm 1.9$ in TE, and $1.9 \pm$ 2.15 in EP. At EP $73 \%$ of plots had two or fewer plants, resulting in a standard deviation greater than the mean. The difference in species richness and density between sites was highly significant $(\mathrm{Z}=3.72, \mathrm{P}=0.0001$ for richness; $\mathrm{Z}=4.05, \mathrm{P}<0.0001$ for density). Species accumulation curves, estimated using the non-parametric Chaol index, showed that the TE curve did not stabilize with accumulated number of species two times greater than that at EP, where the curve did stabilize. Total species estimates for the sites were $163.33 \pm 41.37$ species in TE and $71.61 \pm 24.22$ species in EP (Fig. 2).

In general, for the three dispersal syndromes, plant species richness and density was higher in TE than in EP. At both sites, the richness and density of species dispersed by birds, bats, and other biotic agents was the highest; followed by species dispersed strictly by primates, and finally by species with abiotic dispersal (Fig. 3). The comparison of dispersal syndromes within sites showed significant differences (plant species richness: $\mathrm{H}=53.77, \mathrm{P}$ $<0.0001$ for $\mathrm{TE}$ and $\mathrm{H}=48.06, \mathrm{P}<0.0001$ for

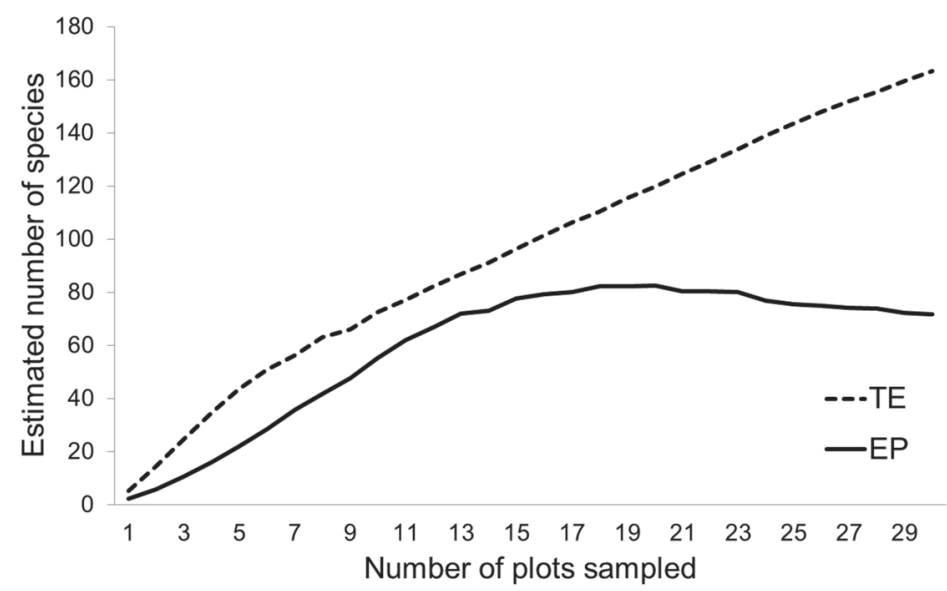

Fig. 2. Seedling species accumulation curves estimated using the nonparametric Chaol index at two sites in Northwestern Ecuador. TE: Tesoro Escondido; EP: El Pambilar. 


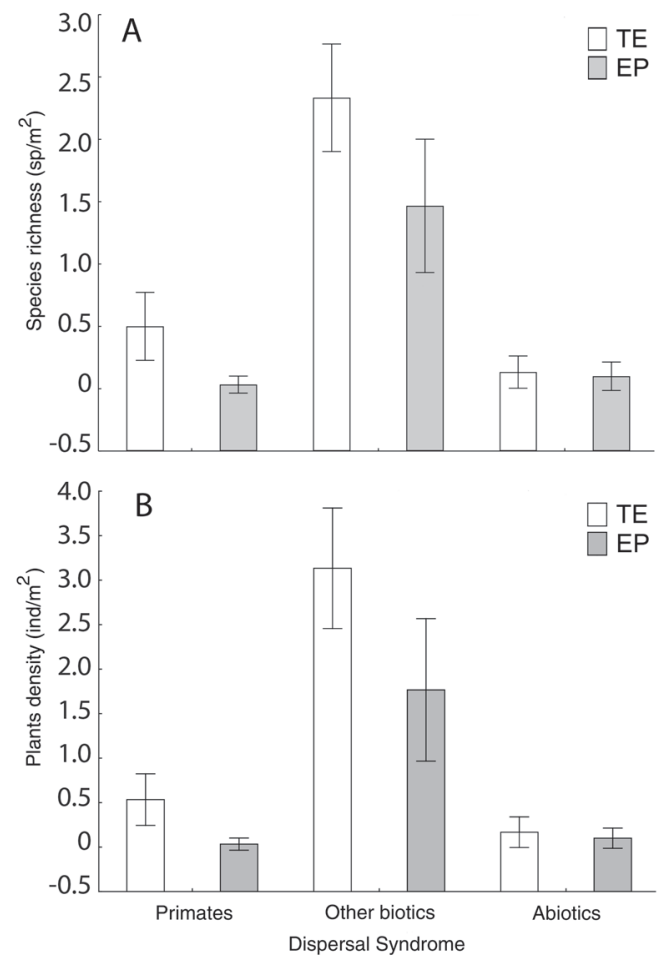

Fig. 3. Species richness (A) and plants density (B) in three dispersal categories at two sites in Northwestern Ecuador. Average and the $95 \%$ confidence intervals. TE: Tesoro Escondido; EP: El Pambilar.

EP; seedling density: $\mathrm{H}=53.33, \mathrm{P}<0.0001$ for $\mathrm{TE}$ and $\mathrm{H}=48.27, \mathrm{P}<0.0001$ for $\mathrm{EP}$ ). The Newman-Keuls test identified only one dispersal pair, without a significant difference in seedling richness and density, the primate dispersed group relative to the abiotically dispersed group. All other pairs showed significant differences. For abiotically dispersed species, there was no difference between sites for either index (species richness: $\mathrm{Z}=0.22, \mathrm{P}$ $=0.82$; density: $\mathrm{Z}=0.24, \mathrm{P}=0.80$ ). The differences between sites were significant for both indices for primate dispersed species (species richness: $Z=2.45, P=0.014$; density: $Z=2.46$, $\mathrm{P}=0.013$ ), as well as for species dispersed by other biotic agents (species richness: $Z=3.08$, $\mathrm{P}=0.002$; density: $\mathrm{Z}=3.42, \mathrm{P}=0.0006$ ).

\section{DISCUSSION}

A distribution model developed by Peck et al. (2011) identified potential spider monkey habitat in Northwestern Ecuador that included both of our study sites. Our physical comparison of the two forests showed no obvious structural reason for the observed differences in primate abundances at the two sites. All indices of forest structure were higher in TE than in EP; however, the two sites are not significantly different in terms of basal area, canopy closure, or height. Forest height, a structural characteristic of demonstrated importance in primate habitat use (Mendes, 1997; Pozo, 2009) is the structural index most similar at these sites $(\mathrm{P}$ $=0.63$ ), and is thus unlikely to explain the differences in primate abundances. However, the difference in tree density was highly significant. Nevertheless, other species of genus Ateles, Alouatta, and Cebus use forests with similar or lower densities of large trees than those found in EP. For example, Alouatta palliata and Cebus capucinus are found on Barro Colorado Island in Panama (Leighton \& Leighton, 1982; Wehncke et al., 2003) where tree density is 371-383 trees / ha (DeWalt \& Chave, 2004); Alouatta palliata is also found at La Selva Biological Station in Costa Rica (Stoner, 1996) where tree density ranges between 426515 trees / ha (DeWalt \& Chave, 2004); Ateles geoffroyi and Alouatta palliata occupy forest fragments in Los Tuxtlas, Mexico (Estrada \& Coates-Estrada, 1996), where tree density is 737-834 trees / ha (Arroyo-Rodríguez, Mandujano, \& Cuende-Fanton, 2005); and Ateles belzebuth, Alouatta seniculus and Cebus albifrons are found in Yasuní in the Ecuadorian Amazon (Pozo \& Youlatos, 2005), where tree density is approximately 701 trees / ha (Valencia et al., 2004). All are similar to the values reported here for both study sites, suggesting that the tree density does not account for the primate differences between EP and TE. The history of human hunting has apparently been different between the two study sites and it is possible that the density differences in trees could be a result of a long period with incomplete or 
diminished dispersal and recruitment at the EP site. Timber related activities would not have caused these differences in tree density as EP has never been commercially exploited. Fruit type and availability are other variables that have been used to compare primate habitats (Effiom et al., 2013); however, fruiting patterns, though not quantified in this study, seemed qualitatively similar at both sites. Future comparisons of phenology and bromatological characteristics of fruits at the two sites might provide greater insight into these as potential factors contributing to the observed differences in primate populations; however, this might also be a result of reduced dispersal of preferred fruits at the site with lower primate density. At the community level there were significant differences between primate abundances at the two sites with spider monkey populations particularly impacted, consistent with our first prediction. Anecdotal evidence suggests that these differences are probably due to hunting by indigenous Chachis (who prefer spider monkeys over the other two primate species) before the EP site was declared a protected area in 2010.

Many animal populations have been documented to diminish as a result of hunting (Carrillo, Won, \& Cuarón, 2000), not only reducing numbers of preferred prey, but altering the structure of the animal community (Peres \& Dolman, 2000; Barrera et al., 2008). A typical result is density compensation, a process in which a decrease in the population of one species can lead to an increase in a less dominant competitor species (McArthur, Diamon, \& Karr, 1972). In the Colombian Amazon, Barrera et al. (2008) found that small and medium sized primates (including Cebus) dominated biomass and density measures relative to large bodied species (Alouatta and Lagothrix) hunted by a nearby indigenous community. In EP, capuchins dominated the primate community, whilst howlers represented $52 \%$ and spider monkeys only $4.3 \%$ of capuchin abundance. This is suggestive of density compensation, but comparisons of the biomass of each species or species densities (parameters not calculated here) would provide more conclusive evidence for the process (Peres \& Dolman 2000; Barrera et al., 2008). There is also the possibility that the spider monkeys were simply more intensively hunted than the other two species. Nasi, Taber, \& van Vliet (2011) note that many human groups in Latin America prefer highly frugivorous species (such as spider monkeys) because their meat is tastier. Moreover, according to Chachi individuals, it is easier to hunt spider monkeys than the other species, since the capuchins are very fast and the howlers very "tough". The evidence for human effects on primate and other mammal populations in EP emphasizes the challenge of biodiversity conservation within this social context, where hunting is a culturally and socioeconomically sanctioned activity and where human subsistence depends on the forest's natural resources. $\mathrm{EP}$ is now a state wildlife refuge and hunting is controlled.

Seedling and sapling species richness and density were significantly higher at the site with greater primate abundance, a finding consistent with our second prediction. The species accumulation curve constructed for young plants in EP stabilized, while that of TE did not, suggesting lower overall diversity in EP. The forests of the Chocó biogeographic region are characterized by a high number of species in relatively limited areas (Galeano, Suárez, \& Balslev, 1998). The accumulation curve based on the Chaol estimator makes its calculations based on the proportion of rare species; in TE there were a total of 46 singletons, while the EP sample included only 26. The assumption is that greater sampling in TE would result in the appearance of additional species until the accumulation curve stabilizes. However, both sites would require a rigorous sampling program due to high regional species richness.

Higher species richness and density for saplings in understory at TE is not conclusive evidence of a causal relationship between these characteristics and greater primate abundance. The observed pattern could conceivably be due to other factors that are important at a small scale, such as topography, edaphic 
characteristics, and light conditions. However, the apparent structural similarity between localities implies that primate seed dispersal may indeed be the critical variable resulting in diminished forest regeneration in EP.

The Janzen (1970) and Connell (1971) model predicts that the absence of dispersal agents will lead to a decline in species richness, at least in young plants. This study is not a direct test of the model such as the investigation carried out by Terborgh et al. (2008), but the finding that seedling richness in EP is significantly lower than in TE is consistent with its basic prediction. Presumably, in EP many seeds are falling directly below their parent plant for lack of frugivorous dispersers; in such high-density, monospecific conditions there is probably high mortality and minimal recruitment, with the result that the understory will comprise of increasingly fewer species. In a few decades, when the current canopy trees begin to die out and become replaced by the current understory, the regenerated forest will be less species rich.

There were more primate dispersed seedlings in TE than in EP, a finding consistent with those of Nuñez-Iturri et al. (2008) in Amazon forests, and of Effiom et al. (2013) in Nigeria. The Amazonian study, using similar methods, reported three times the diversity and number of seedlings of our Chocó sample. This seems likely associated with the greater overall primate diversity in the Amazon, where ten species have been reported, including three atelids (Alouatta seniculus, Ateles chamek and Lagothrix lagotricha). The spider and woolly monkeys are both highly frugivorous. The Choco primate fauna, on the other hand, comprises only two large species, and of these only the spider monkey is highly frugivorous (Tirira, 2008). In Nigeria, the number of plant species dispersed by primates was likewise higher in the hunting free site, where there are relatively high populations of the Western Cross River gorilla, chimpanzees (Pan troglodytes), and mandrills (Mandrillus leucophaeus). Despite the importance of the primate community, there are other factors such as different disturbance histories, the diversity of other dispersal agents, and many abiotic variables that could produce this difference. One of those factors could be post-dispersal events and defecation patterns (Ponce-Santizo, Andresen, Cano, \& Cuarón, 2006). Post-dispersal refers to the secondary movement of seed such as when dung beetles are drawn by defecation (Nichols et al., 2008), resulting in some cases in burial of the seeds which could increase probability of establishment of plants in the forest (Andresen \& Levey, 2004). These aspects were not evaluated in this study, and there are no studies of this kind in Northwest Ecuador. However, the higher abundance of primates in TE could itself increase the post-dispersal process, whereas in EP, lower primate abundance (and possibly lower abundance of others mammals) could limit the abundance of dung beetles. Thus, hunting of primates could result in cascading effects, both direct and indirect, on species diversity throughout the ecosystem. Defecation patterns depend of the behavior and ecology of each primate, for example, howler monkeys generally defecate in group and spider monkeys defecate individually, but this difference does not affect post-dispersal (Ponce-Santizo et al., 2006). In any case, future comparisons evaluating how these differences affect plant recruitment and forest regeneration will provide useful empirical evidence regarding the importance of postdispersal factors.

Primates are important seed dispersers in the Chocó forests, but there are also other large mammalian frugivores such as peccaries, deer and rodents, which generally destroy or do not swallow seeds (Beck-King, von Helversen, \& Beck-King, 1999; Bodmer, 1991; Forget, Muñoz, \& Leigh, 1994; Sork, 1987). There are also large frugivorous birds such as toucans and macaws, but they are unlikely to use all plants. Stevenson (2007) found that Lagothrix lagotricha manipulated seeds of $35 \%$ of the plants present in a forest in the Colombian Amazon, while the entire avifauna manipulated the same percentage of total species. Still it is important to point out the extensive overlap among the diets of many of these species; the 
assignment of dispersal syndrome based solely on seed size is a first approximation, needing greater refinement based on direct observations. Some seeds greater than $15 \mathrm{~mm}$ in length, for instance, are not consumed by primates due to toxicity (e.g. Andira inermis), low nutritional value, an extremely hard or tough epicarp or characteristics more adapted to bird or bat dispersal. Nevertheless, seed size permits comparisons among studies. Nuñez-Iturri et al. (2008) quantified a loss of $46 \%$ of primate dispersed species (defined as those with seeds $\geq 15 \mathrm{~mm}$ and sapling height $\leq 1 \mathrm{~m}$ ) or 1 species per square meter; in comparison, the species loss in Northwestern Ecuador forest, where the loss was $92 \%$, or 2 species per square meter (plants with seeds $\geq 15 \mathrm{~mm}$ and sapling height $\leq 5 \mathrm{~m}$ ). It is important to note the difference in height criterion for the two sites.

There was a loss in plant species number in EP despite the similarity to TE in the abundance of capuchin monkeys. Capuchins do eat fruits, but not exclusively (Defler, 2010); moreover their handling of fruits, probability of swallowing the seeds, ranging behavior, and other aspects of their basic natural history result in important differences in seed dispersal between them and the spider monkeys. The reduced plant species diversity at EP is consistent with the conclusion that spider monkeys play an especially important role in dispersal that is not replaced even by density compensation between primate species.

The richness and density of young plants dispersed by other biotic agents in the Chocó were affected differently by hunting. In Peru, both indices were higher in the hunted than in the non-hunted site, suggesting the possibility of density compensation (Nuñez-Iturri \& Howe, 2007; Nuñez-Iturri et al., 2008), however in Ecuador, the non-hunted understory was both richer in species and higher in density than the hunted site. The reasons for this macrogeographic difference are not obvious. It is clear, nevertheless, that in the Chocó bird and bat dispersed plant species were not released by reduced recruitment of primate dispersed species. The density of seedlings dispersed abiotically was no greater in EP than in TE. The sampling criteria of this study may have biased this result, since lianas and herbaceous plants were excluded; these represent 10.3-24.5 $\%$ of all the vascular plants present in 0.1 ha of Chocó forest (Galeano et al., 1998). It is likely that the space in the understory freed by low recruitment of biotically dispersed species is being occupied by herb and liana seedlings, which tend moreover to be heliophiles (Schnitzer \& Bongers, 2002) and would be favored by a less dense canopy. Canopy closure was lower in EP than in TE, though not significantly and it is possible that a more intensive sampling effort would reveal whether the difference is real.

The interruption of ecological processes, such as the plant animal interactions associated with frugivory and seed dispersal has been widely shown to diminish plant species richness, one of the characteristics for which the Chocó biogeographic region is a global conservation priority. Maintaining intact wildlife populations, with special emphasis on primates due to their vulnerability and wideranging movements appears to be necessary to maintain plant diversity in these forests. Moreover, these primates disperse the seeds of plants used by the human communities in the study zone-for wood (e.g., Virola elongata and Otoba novogranatensis), traditional medicines (Mollinedia ovate), and food (Pouteria glomerata). For these empirical reasons it is vital to designate the primates in El Pambilar Wildlife Refuge as conservation priorities, particularly the critically endangered brown-headed spider monkey. Moreover, in TE greater publicity and economic support are needed to ensure success of the current conservation initiative that involves the local community in scientific projects as well as working to improve income from cacao and halting deforestation.

These results should not be extrapolated to the entire Chocó hotspot, as we investigated only two sample areas, and the entire region covers over $127000 \mathrm{~km}^{2}$ (Myers, 1988). Nevertheless this study serves as a reference point and justification for further investigation in the 
region, evaluating the ecological importance of primates and other threatened fauna, in the maintenance of ecological integrity of forests, and catalyzing effective conservation throughout the biome.

\section{ACKNOWLEDGMENTS}

This study is part of the project, "Conservation of the coastal spider monkey (Ateles fusciceps fusciceps) in the context of anthropogenic activities in Northwestern Ecuador", financed by the Holly Hill Charitable Trust and Scott Rasmussen Trust. We gratefully acknowledge the contributions of the parabiologists, thesis students, and volunteers who participated in the primate surveys; Denise Spaan for connectivity data in TE; Fundación Cambugan, the National Herbarium of Ecuador (QCNE), and the Pambilar Wildlife Refuge for logistical support; the inhabitants of the Tesoro Escondido Cooperative, especially Javier Cedeño, the Paredes family, Yonathan Loor, and Galo Conde for their collaboration in the field work; and Angélica Martínez Alfonso for the figures edition.

\section{RESUMEN}

Comparación de la regeneración del bosque en dos sitios con diferente abundancia de primates en el Noroccidente de Ecuador. Ha habido un incremento de la evidencia sobre el importante papel ecológico de los primates grandes como dispersores de semillas para el mantenimiento de la diversidad del bosque. Este estudio compara la regeneración del bosque en dos sitios con diferente abundancia de primates en el Chocó ecuatoriano. Las predicciones son: (1) la abundancia de primates será significativamente diferente en los dos sitios; (2) la riqueza de especies y la densidad de plantas del sotobosque será mayor en la localidad con mayor abundancia de primates $y$, (3) la localidad con menos primates tendrá mayor riqueza de especies y densidad de plantas que aquellas especies dispersadas por otros mecanismos bióticos. Se compararon dos sitios: una cooperativa campesina (TE) y un Refugio de Vida Silvestre (EP). Allí habitan tres especies de primates: el aullador negro (Alouatta palliata), el mono araña de cabeza café (Ateles fusciceps fusciceps) y el mono capuchino (Cebus capucinus). Se caracterizó la estructura del dosel usando muestreos en punto-cuadrante, se determinó la abundancia de primates y se muestrearon plántulas en parcelas de $1 \mathrm{~m}^{2}$, clasificando las especies de acuerdo con tres síndromes de dispersión: dispersadas por primates, dispersadas por otros agentes bióticos y dispersadas por agentes abióticos. Se compararon ambos sitios en términos de abundancia de primates (grupos e individuos por día) y características de la regeneración (densidad de plantas, riqueza de especies, y síndrome de dispersión). Se hicieron comparaciones en cada sitio y se construyeron curvas de acumulación de especies. El bosque fue estructuralmente similar, con una abundancia mayor de $A$. f. fusciceps en TE. Los encuentros para las otras dos especies de primates fueron similares en ambos sitios. La densidad y riqueza de plántulas del sotobosque fue significativamente mayor en TE y la curva de acumulación de especies no se estabilizó pero sí lo hizo en EP. Se observó mayor densidad y riqueza de plántulas dispersadas por primates en TE con dominancia del grupo de plántulas expuestas a otros agentes bióticos y abióticos en ambos sitios. Los resultados son consistentes con los de otros estudios que investigan el papel de los grandes primates frugívoros en la regeneración del bosque y puntualizan un patrón general: la diversidad futura de los bosques tropicales de tierras bajas podría depender del mantenimiento de poblaciones robustas de primates grandes. Es probable que la alta diversidad de árboles en los bosques lluviosos del Chocó dependa de la conservación de sus primates, entre ellos el mono araña de cabeza café, una especie críticamente amenazada.

Palabras clave: Alouatta palliata, Ateles fusciceps fusciceps, Cebus capucinus, Chocó biogeográfico, dispersión de semillas, puntos calientes de biodiversidad, regeneración de bosques.

\section{REFERENCES}

Andresen, E. (2002). Primary seed dispersal by red howler monkeys and the effect of defecation patterns on the fate of dispersed seeds. Biotropica, 34, 261-272.

Andresen, E., \& Levey, D. J. (2004). Effects of dung and seed size on secondary dispersal, seed predation, and seedling establishment of rain forest trees. Oecologia, 139, 145-154.

Arroyo-Rodríguez, V., Mandujano, S., \& Cuende-Fanton, C. (2005). Ocupación de parches de selva por monos aulladores Alouatta palliata mexicana en tres paisajes con diferente grado de fragmentación en Los Tuxtlas, México. Universidad y Ciencia, 2, 23-34.

Barrera, V. A., Zambrano, J., \& Stevenson, P. R. (2008). Diversity of regenerating plants and seed dispersal in two canopy trees from Colombian Amazon forests with different hunting pressure. Revista de Biología Tropical, 56, 1531-1542.

Beck-King, H., von Helversen, O., \& Beck-King, R. (1999). Home range, population density, and food resources of Agouti paca (Rodentia: Agoutidae) in 
Costa Rica: a study using alternative methods. Biotropica, 31, 675-685.

Bodmer, R. E. (1991). Strategies of seed dispersal and seed predation in Amazonian ungulates. Biotropica, $23,255-261$.

Calle-Rendón, B. R., Moreno, F., \& Cárdenas-López, D. (2011). Relación entre suelos y estructura del bosque en la Amazonía colombiana. Revista de Biología Tropical, 59, 1307-1322.

Carrillo, E., Won, G., \& Cuarón, A. D. (2000). Monitoring mammal populations in Costa Rican protected areas under different hunting restrictions. Conservation Biology, 14, 1580-1591.

Carson, W. P., Anderson, J. T., Leigh Jr, E. G., \& Schnitzer, S. A. (2008). Challenges associated with testing and falsifying the Janzen-Connell hypothesis: a review and critique. In W. P. Carson \& S. A. Schnitzer (Eds.), Tropical forest community ecology (pp. 210-241). Oxford, United Kingdom: Wiley-Blackwell.

Casas, L. F. (2010). Heterogeneidad estructural de un bosque de tierra firme de la Amazonia colombiana y su relación con algunas variables ambientales $(\mathrm{M}$. Sc. Dissertation). Universidad Nacional de Colombia, Colombia.

Chao, A. (1984). Nonparametric estimation of the number of classes in a population. Scandinavian Journal of Statistics, 11, 265-270.

Chapman, C. A. (1995). Primate seed dispersal: coevolution and conservation implications. Evolutionary Anthropology, 4, 74-82.

Colwell, R. K. (2013). EstimateS: Statistical estimation of species richness and shared species from samples, version 9.0. Storrs, USA: University of Connecticut. Retrieved from http://purl.oclc.org/estimates

Connell, J. H. (1971). On the role of natural enemies in preventing competitive exclusion in some marine animals and in rain forest trees. In P. J. den Boer \& G. R. Gradwell (Eds.), Dynamics of populations (pp. 298-312). Wageningen, Holland: Pudoc.

Corlett, R. T., \& Primack, R. B. (2008). Tropical rainforest conservation: a global perspective. In W. P. Carson, \& S. A. Schnitzer (Eds.), Tropical forest community ecology (pp. 442-457). Oxford, United Kingdom: Wiley-Blackwell.

Dalling, J. W., \& John, R. (2008). Seed limitation and the coexistence of pioneer tree species. In W. P. Carson, \& S. A. Schnitzer (Eds.), Tropical forest community ecology (pp. 242-253). Oxford, United Kingdom: Wiley-Blackwell.

Defler, T. R. (2010). Historia Natural de los primates colombianos. Bogotá, Colombia: Universidad Nacional de Colombia and Conservación Internacional.
Defler, T. R., \& Defler, S. B. (1996). Diet of a group of Lagothrix lagothricha lagothricha in southeastern Colombia. International Journal of Primatology, 17, 161-190.

DeWalt, S. J., \& Chave, J. (2004). Structure and biomass of four lowland neotropical forests. Biotropica, 36, 7-19.

Effiom, E. O., Nuñez-Iturri, G., Smith, H. G., Ottosson, U., \& Olsson, O. (2013). Bushmeat hunting changes regeneration of African rainforests. Proceedings of the Royal Society B-Biological Sciences, 280, 2013026

Estrada, A., \& Coates-Estrada, R. (1996). Tropical rain forest fragmentation and wild populations of primates at Los Tuxtlas, Mexico. International Journal of Primatology, 17, 759-783.

Forget, P. M., Muñoz, E., \& Leigh Jr, E. G. (1994). Predation by rodents and bruchid beetles on seeds of Scheelea palms on Barro Colorado Island, Panama. Biotropica, 26, 420-426.

Galeano, G., Suárez, S., \& Balslev, H. (1998). Vascular plant species count in a wet forest in the Chocó area on the pacific coast of Colombia. Biodiversity and Conservation, 7, 1563-1575.

Ganzhorn, J. U., Rakotondranary, S. J., \& Ratovonamana, Y. R. (2011). Habitat description and phenology. In J. M. Setchell, \& D. J. Curtis (Eds.), Field and laboratory methods in primatology: a practical guide (pp. 51-68). Cambridge, United Kingdom: Cambridge University Press.

Janzen, D. H. (1970). Herbivores and the number of tree species in tropical forests. The American Naturalist, 104, 501-528.

Jennings, S. B., Brown, N. D., \& Sheil, D. (1999). Assessing forest canopies and understory illumination: canopy closure, canopy cover and other measures. Forestry, 72, 59-73.

Justicia, R. M. (2007). Ecuador's Choco Andean corridor: a landscape approach for conservation and sustainable development ( $\mathrm{Ph}$. D. Dissertation). University of Georgia, United States of America.

Knogge, C., Heymann, E. W., \& Tirado, E. R. (1998). Seed dispersal of Asplundia peruviana (Cyclanthaceae) by the primate Saguinus fuscicollis. Journal of Tropical Ecology, 14, 99-102.

Leighton, M., \& Leighton, D. R. (1982). The relationship of size of feeding aggregate to size of food patch: howler monkeys (Alouatta palliata) feeding in Trichilia cipo fruit trees on Barro Colorado Island. Biotropica, 14, 81-90.

Link, A., \& Di Fiore, A. (2006). Seed dispersal by spider monkeys and its importance in the maintenance of 
neotropical rain-forest diversity. Journal of Tropical Ecology, 22, 235-246.

McArthur, R. H., Diamon, J. M., \& Karr, J. R. (1972). Density compensation in island faunas. Ecology, 53, 330-342.

McConkey, K. R., Aldy, F., Ario, A., \& Chivers, D. J. (2002). Selection of fruit by gibbons (Hylobates muelleri $\times$ agilis $)$ in the rain forests of Central Borneo. International Journal of Primatology, 23, 123-145.

Melo, O. A., \& Vargas, R. (2002) Evaluación ecológica y silvicultural de ecosistemas boscosos. Ibagué, Colombia: Universidad del Tolima, CRQ, Carder, Corpocaldas and Cortolima.

Mendes, A. (1997). Habitat partitioning among primates in Maracá Island, Roraima, northern Brazilian Amazonia. International Journal of Primatology, 18, 131-157.

Ministerio del Ambiente (2011). Plan de Manejo del Refugio de Vida Silvestre El Pambilar. Quito, Ecuador: Ministerio del Ambiente.

Mittermeier, R. A., Myers, N., Thomsen, J. B., da Fonseca, G. A. B., \& Olivieri, S. (1998). Biodiversity hotspots and major tropical wilderness areas: approaches to setting conservation priorities. Conservation Biology, $12,516-520$.

Mittermeier, R. A., Schwitzer, C., Rylands, A. B., Taylor, L. A., Chiozza, F., Williamson, E. A., \& Wallis, J. (2012). Primates in peril: the world's 25 most endangered primates 2012-2014. Bristol, United Kingdom: IUCN/SSC Primate Specialist Group (PSG), International Primatological Society (IPS), Conservation International (CI) and Bristol Conservation and Science Foundation.

Moscoso, P., \& Peck, M. (2012). A conservation strategy for the critically endangered brown-headed spider monkey (Ateles fusciceps) (Primates, Atelidae) in the Coop Tesoro (NW Ecuador). (Unpublished report prepared for Primenet).

Muller-Landau, H. C. (2008). Colonization-related tradeoffs in tropical forests and their role in the maintenance of plant species diversity. In W. P. Carson, \& S. A. Schnitzer (Eds.), Tropical forest community ecology (pp. 182-194). Oxford, United Kingdom: Wiley-Blackwell.

Myers, N. (1988). Threatened biotas:"hotspots" in tropical forests. Environmentalist, 8, 187-208.

Myers, N. (1990). The biodiversity challenge: expanded hot-spots analysis. Environmentalist, 10, 243-256.

Myers, N., Mittermeier, R. A., Mittermeier, C. G., da Fonseca, G. A. B., \& Kent, J. (2000). Biodiversity hotspots for conservation priorities. Nature, 403, 853-858.
Nasi, R., Taber, A., \& van Vliet, N. (2011). Empty forests, empty stomachs? bushmeat and livelihoods in the Congo and Amazon basins. International Forestry Review, 13, 355-368.

Nichols, E., Spectora, S., Louzadab, J., Larsenc, T., Amezquitad, S., Favilad, M. E., \& The Scarabaeinae Research Network. (2008). Ecological functions and ecosystem services provided by Scarabaeinae dung beetles. Biological Conservation, 141, 1461-1474.

Nuñez-lturri, G., \& Howe, H. F. (2007). Bushmeat and the fate of trees with seeds dispersed by large primates in a lowland rain forest in western Amazonia. Biotropica, 39, 348-354.

Nuñez-lturri, G., Olsson, O., \& Howe, H. F. (2008). Hunting reduces recruitment of primate-dispersed trees in Amazonian Peru. Biological Conservation, 141, 1536-1546.

Olson, D. M., \& Dinerstein, E. (1998). The global 200: a representation approach to conserving the earth's most biologically valuable ecoregions. Conservation Biology, 12, 502-515.

Olson, D. M., \& Dinerstein, E. (2002). The global 200: priority ecoregions for global conservation. Annals of the Missouri Botanical Garden, 89, 199-224.

Peck, M., Thorn, J., Mariscal, A., Baird, A., Tirira, D., \& Kniveton, D. (2011). Focusing conservation efforts for the critically endangered brown-headed spider monkey (Ateles fusciceps) using remote sensing, modeling, and playback survey methods. International Journal of Primatology, 32, 134-148.

Peres, C. A. (1999). General guidelines for standardizing line-transect surveys of tropical forest primates. $\mathrm{NeO}$ tropical Primates, 7, 11-16.

Peres, C. A., \& Dolman, P. M. (2000). Density compensation in neotropical primate communities: evidence from 56 hunted and nonhunted Amazonian forests of varying productivity. Oecologia, 122, 175-189.

Ponce-Santizo, G., Andresen, E., Cano, E., \& Cuarón, A. D. (2006). Dispersión primaria de semillas por primates y dispersión secundaria por escarabajos coprófagos en Tikal, Guatemala. Biotropica, 38, 390-397.

Pozo, W. E. (2009). Uso preferencial de hábitat en primates atélidos en el Parque Nacional Yasuní, Ecuador. Serie Zoológica, 5, 25-34.

Pozo, W. E., \& Youlatos, D. (2005). Estudio sinecológico de nueve especies de primates del Parque Nacional Yasuní, Ecuador. Revista Politécnica, Biología, 26, 86-107.

Schnitzer, S. A., \& Bongers, F. (2002). The ecology of lianas and their role in forests. Trends in Ecology and Evolution, 17, 223-230. 
Schnitzer, S. A., Mascaro, J., \& Carson, W. P. (2008). Treefall gaps and the maintenance of plant species diversity in tropical forests. In W. P. Carson, \& S. A. Schnitzer (Eds.), Tropical forest community ecology (pp. 196-209). Oxford, United Kingdom: Wiley-Blackwell.

Sierra, R., \& Stallings, J. (1998). The dynamics and social organization of tropical deforestation in northwest Ecuador, 1983-1995. Human Ecology, 26, 135-161.

Sork, V. L. (1987). Effects of predation and light on seedling establishment in Gustavia superba. Ecology, 68, $1341-1350$

Southgate, D., \& Whitaker, M. (1992). Promoting resource degradation in Latin America: tropical deforestation, soil erosion, and coastal ecosystem disturbance in Ecuador. Economic Development and Cultural Change, 40, 787-807.

Stevenson, P. R. (2000). Seed dispersal by woolly monkeys (Lagothrix lagothricha) at Tinigua National Park, Colombia: dispersal distance, germination rates, and dispersal quantity. American Journal of Primatology, 50, 275-289.

Stevenson, P. R. (2007). Estimates of the number of seeds dispersed by a population of primates in a lowland forest in western Amazonia. In A. J. Dennis, E. W. Schupp, R. J. Green, \& D. W. Westcott (Eds.), Seed dispersal: theory and its application in a changing world (pp. 340-362). Wallingford, United Kingdom: CABI Publishing.

Stevenson, P. R. (2011). The abundance of large ateline monkeys is positively associated with the diversity of plants regenerating in neotropical forests. Biotropica, $43,512-519$.
Stoner, K. E. (1996). Habitat selection and seasonal patterns of activity and foraging of mantled howling monkeys (Alouatta palliata) in northeastern Costa Rica. International Journal of Primatology, 17, 1-30.

Terborgh, J., Nuñez-lturri, G., Pitman, N. C. A., Cornejo, F. H., Alvarez, P., Swamy, V., Pringle, E. G., \& Timothy, C. E. (2008). Tree recruitment in an empty forest. Ecology, 89, 1757-1768.

Tirira, D. (2001). Libro Rojo de los Mamíferos del Ecuador. Quito, Ecuador: Simbioe, EcoCiencia, Ministerio del Ambiente and UICN.

Tirira, D. (2008) Mamíferos de los bosques húmedos del noroccidente de Ecuador. Quito, Ecuador: Murciélago blanco.

Valencia, R., Foster, R. B., Villa, G., Condit, R., Svenning, J. C., Hernández, C., Romoleroux, K., Losos, E., Magård, E., \& Balslev, H. (2004). Tree species distributions and local habitat variation in the Amazon: large forest plot in eastern Ecuador. Journal of Eco$\log y$, 92, 214-229.

Wehncke, E. V., Hubbell, S. P., Foster, R. B., \& Dalling, W. (2003). Seed dispersal patterns produced by white-faced monkeys: implications for the dispersal limitation of neotropical tree species. Journal of Ecology, 91, 677-685.

Wrangham, R. W., Chapman, C. A., \& Chapman, L. J. (1994). Seed dispersal by forest chimpanzees in Uganda. Journal of Tropical Ecology, 10, 355-368.

Zimmerman, J. K., Thompson, J., \& Brokaw, N. (2008). Large tropical forest dynamics plots: testing explanations for the maintenance of species diversity. In W. P. Carson, \& S. A. Schnitzer (Eds.), Tropical forest community ecology (pp. 98-117). Oxford, United Kingdom: Wiley-Blackwell. 